Mihalis KAVARATZIS*

\title{
WHAT CAN WE LEARN FROM CITY MARKETING PRACTICE?
}

\begin{abstract}
It is evident in contemporary urban studies that the interest in city marketing both as a practice within urban centre management and as an academic sub-discipline has accelerated. There remain, however, several issues that need clarification before an agreement can be reached as to the exact effects and potential of city marketing as a tool of economic and socio-cultural development. A particular gap can be noticed between theoretical suggestions on the ways in which marketing should be understood and used within cities and the practical implementation as this can be observed in contemporary cities. A common view on this issue highlights the need for practitioners to follow theoretical ideas but the practice can also be a source of useful lessons that might enrich the theory. This paper investigates marketing and branding practices of two European cities in order to extract from the practice lessons that will support the theoretical development of city marketing and city branding and might contribute towards bridging this gap. The cities investigated are Amsterdam and Budapest, both of which provide valuable insights into the challenges of an effective city marketing implementation.
\end{abstract}

Key words: place marketing, Amsterdam, Budapest.

\section{INTRODUCTION}

For several decades now, cities all over the world have been applying marketing techniques and increasingly adopting a marketing philosophy to meet their operational and strategic goals. City marketing has grown into an established field of research and a growing academic sub-discipline, which has attracted the interest of commentators from several fields and has resulted in a substantial body of publications on the wider city marketing process (e.g. Ashworth and

\footnotetext{
* Mihalis KAVARATZIS, Urban and Regional Studies Institute, University of Groningen, The Netherlands, International Business School, Budapest, Hungary.
} 
Voogd, 1990; Kotler et al., 1999) and on specific issues or examples (e.g. Gold and Ward, 1994; Berg and Braun, 1999). However, the transfer of marketing knowledge to the operational environment of cities proves a cause of difficulties and misalignments, mostly due to the peculiar nature of places in general and cities in particular as marketable assets. Despite the accumulated experience, significant issues surrounding the application of city marketing remain in need of further theoretical development and practical clarification. This article examines two European cities (Amsterdam and Budapest) providing a commentary on their current marketing efforts. The article includes grounded suggestions for the future directions that both the theoretical development and the practical application of city marketing should take. Within city marketing, pivotal significance is attributed to the role of city branding as a distinct focus and guiding principle for the wider marketing effort.

City marketing is a process that includes a wide set of activities. It starts with a careful analysis of the city's current situation through extensive research on the city's assets, opportunities and audiences (Kavaratzis and Ashworth, 2007). The second step is identifying and choosing a certain vision for the city and the goals that should be achieved with the cooperation and agreement of as broad a range of stakeholders as possible. What comes next is the phase of planning specific projects that will collectively achieve the goals set and allocating clear roles for the participating bodies. This is followed by the phase of active implementation of city marketing measures that can be spatial/functional, financial, organisational and promotional (Ashworth and Voogd, 1990). The process ends with monitoring and regularly evaluating the results of all activities; an evaluation that only leads to the repetition of the whole process adapted to the new knowledge and experience gained. It is important here to clarify two issues. First, that city marketing is a long-term process that cannot be implemented in parts or only to a certain extent. Secondly, that promotional activities constitute only a fraction of the whole process and should not be considered an alternative for strategic marketing (as is the case in a large part of city marketing practice). A distinction is also necessary concerning the role of branding, which in many cases is understood as only the development of logos and slogans on the city's promotional material. However, branding is again a wide process that does not substitute the marketing process but may provide a distinct focus on the communicative aspect of all marketing measures (Kavaratzis, 2004).

One notable aspect of city marketing is the evident discrepancy between theory and practice. The literature mentioned above has attempted to provide, on the one hand, clarifications concerning the exact nature of the activity and its potential to assist urban development and, on the other, effective guidelines on practical implementation. Despite this effort, the practice of city marketing shows that there is a limited understanding of the concept, with two main 
characteristics. First, marketing is, in most cases, not implemented as a process but as a set of fragmented actions and, second, marketing is still confused with one of its elements, namely promotional activities. The intention of this article is to extract from the practice in the two cities examined, lessons that will support the theoretical development of city marketing and city branding and might contribute towards bridging this gap.

\section{THE CASE OF AMSTERDAM}

Amsterdam is a city with a long trade tradition and a strong reputation for culture and innovation. However, the position of Amsterdam as a major national and international cultural centre has for some time been threatened by a sharpening of competition from other cities both within and outside The Netherlands (e.g. European Cities Monitor 2005, 2006). Amsterdam has recently engaged itself to a fundamental attempt at a strategic marketing involving a far-reaching examination of stakeholders, goals and competitive positioning (see Kavaratzis and Ashworth, 2007). The general motivation and main goals of this attempt are rooted in the desire to improve Amsterdam's attractiveness to local and international audiences and to retune the city's international image.

Three specific motives have stimulated Amsterdam to invest in city marketing. First, the identified need to improve Amsterdam's position in several cityrankings, which represents a common view which looks at city marketing as a response to increasing interurban competition (Kotler et al., 1999; Berg and Braun, 1999). Secondly, the appreciation that one of the main elements of the city's international image associated with the liberal attitude towards soft drugs and prostitution is now seen as inappropriate, as it overshadows other more desirable aspects of the city's aspirations. This is a clear example of city marketing being used as a method to re-image localities and this is a major reason for the acceleration of the use of city branding. A final, equally important, motive is the widespread view that the city can only gain from a systematic and structured use of city marketing; that city marketing is a powerful tool in the hands of city management and, if used appropriately, it can promote all aspects of urban development. This motive, explicitly demonstrates the implementation of city marketing as a place management philosophy (Kavaratzis and Ashworth, 2005). In this case city marketing is not called upon as a crisis-solving mechanism to provide immediate solutions to urgent problems but, rather as a proactive strategy, as a crisis-prevention mechanism and for it to be effective it needs long term orientation and consistency. 


\subsection{Major Steps in Marketing Amsterdam}

This section describes the process that was followed in the city of Amsterdam in order to develop the new marketing initiative. The beginning of the marketing effort was to undertake a long and elaborate research process. The importance of research and auditing as the first step of the marketing process has been highlighted in all city marketing literature (e.g. Ashworth and Voogd, 1990). Knowledge of existing demand, existing images and associations and the problems which city marketing is setting out to solve or mitigate is a vital first step of the city marketing process. First, a benchmark study was conducted that compared the practice of city marketing in 4 cities (Barcelona, Berlin, Dublin, Rotterdam) undertaken by a communications agency (Gemeente Amsterdam, 2003). The choice of the specific cities was based on the estimation of those cities as major competitors of Amsterdam. The general conclusion of this study was that Amsterdam needed to intensify its marketing efforts. More specifically it was shown that Amsterdam had not pointed out its advantages as clearly as the rest of the cities, it had not done enough to showcase improvements in the city to international audiences and that it did not emphatically opt for key values that would capture the city's essence (Gemeente Amsterdam, 2003). Furthermore, the research identified a lack of responsibility for the Amsterdam brand, something upon which other cities were seen to place more significance.

A consultancy took over the task of suggesting specific methods, goals and processes for the marketing effort and proposing an appropriate and effective organisational structure. Numerous interviews were conducted with selected people with a significant role in the city, aiming to identify the respondents' view on the unique elements of Amsterdam so as to establish the main values on which to base the marketing and branding effort. The results were combined with other sources, namely specialist literature on city marketing, policy documents and travel guides (City of Amsterdam, 2003). Based on the analysis of the data collected, a selection of sixteen dimensions of the city was deduced, which was considered to adequately represent the versatility of Amsterdam and what it means for its audiences (City of Amsterdam, 2003). Afterwards, and in an attempt to deal with the issue in a more bottom-up way, they extended their research on residents of the city using questionnaires, in which the respondents had to attribute points assessing how the city performed according to them in the sixteen dimensions. This evaluation was used to establish a picture of priorities and opportunities for the current image and for what the city is aiming at, represented in the form of a spider's-web (figure 1). 


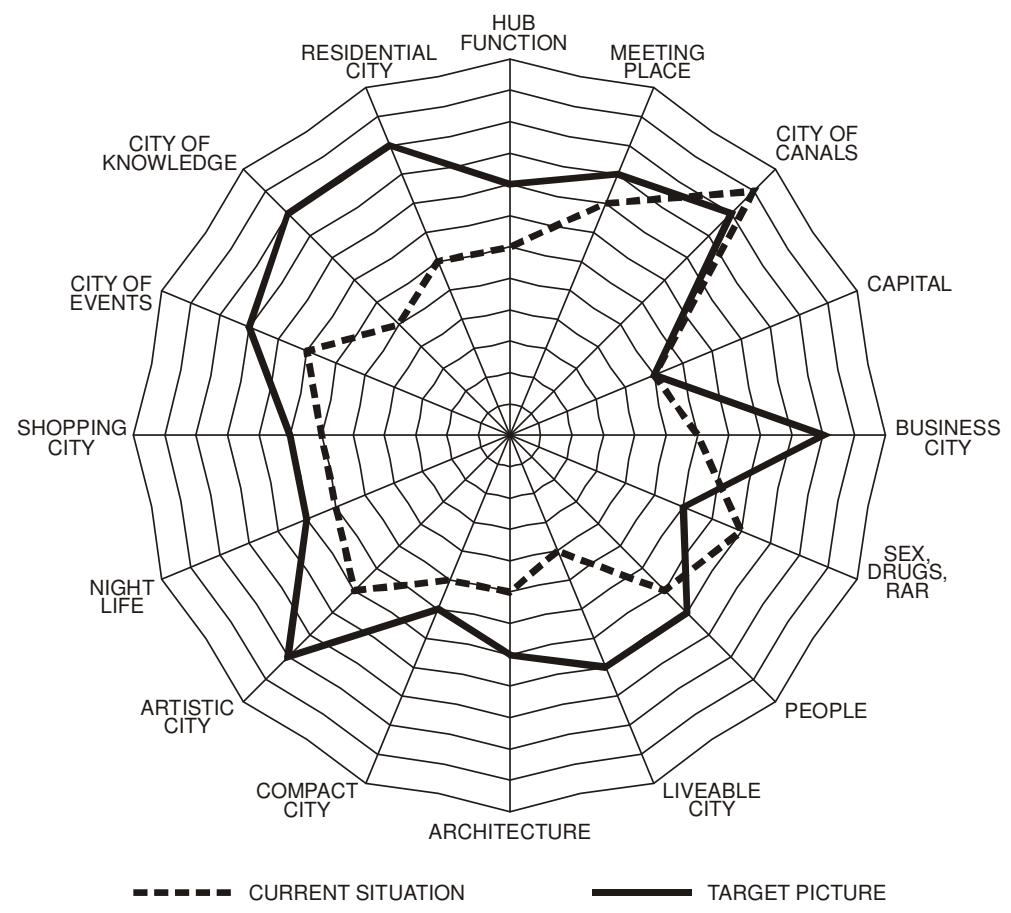

Fig. 1. The Amsterdam spider's-web

The second stage of the new marketing initiative of the city was concerned with the identification of a vision for the city that would also provide the main marketing goals. In an attempt to gain clearer focus for later activities, they proceeded to choose six of the above dimensions of Amsterdam as "priority dimensions' (city of culture, city of canals, city of meetings, city of knowledge, business city and residential city). The first three are regarded as 'strong' in that they were recognised by respondents as significant assets (despite the fact that three of the dimensions obviously associated with a city of culture, namely artistic city, city of events and city of knowledge, need stronger efforts), while the second three are relatively 'weak' being not recognised and thus needing attention. The explicit goal of the whole marketing effort is to maintain the city's strong position in the first three and strengthen the position of Amsterdam in the rest. Furthermore, Amsterdam chose to distinguish itself through the combination of three core values on which the brand of the city should be based. Those values are creativity, innovation and the spirit of commerce and they are thought to express the 'real' meaning of the city and that these have been the city's strengths for centuries. Of course, it remains unclear in what way these values are the core values of the city; what makes Amsterdam more creative than any other city, for instance? The officials in Amsterdam followed their own way to 
make the necessary selections and, in a matter as complex as the characteristics of a city, no selection can be faultless.

The choice of the sixteen dimensions of the city and their transformation first into three core values and then, as will be discussed later, into one slogan is ambiguous. The dimensions that are thought to express all aspects of the city is based on the previous research but, as valid as this research has been, it is not clear exactly whose choice these dimensions are. One could easily argue for the inclusion of others or against some chosen ones or attribute less importance to others. This is especially the case for the six dimensions that achieved a 'priority' status. Furthermore, the exact way of deducing the three core values from a possible list of many more values that could also be used, is not clear and the final core values seem to have been chosen by the consultancy, which does not mean that they are necessarily wrong or necessarily right. However, a very important point to be raised at this point is the fact that the choices of the dimensions and values seem to have gained the support of all participants in marketing Amsterdam. Although it cannot be appreciated if the support comes from a genuine agreement or a convenient silence, this support might prove to be the crucial factor in the effectiveness of the whole effort.

Table 1. Partners in Amsterdam Partners

\begin{tabular}{l}
\hline $\begin{array}{l}\text { Seven departments of the municipality (e.g. Department of Communication, Department of } \\
\text { Economic Affairs etc.) }\end{array}$ \\
\hline Amsterdam Area (eight neighbouring municipalities and the Province of North Holland) \\
\hline $\begin{array}{l}\text { The Business Community (the regional Chamber of Commerce and several private companies } \\
\text { from large multinationals to small local companies) }\end{array}$ \\
$\begin{array}{l}\text { Covenant Partners (eight organisations that were already involved in marketing the city and have } \\
\text { an active role in supporting and advising on strategies and practical issues) }\end{array}$
\end{tabular}

Source: City of Amsterdam (2004, p. 31).

The organisation and coordination of the marketing effort was the next step followed in Amsterdam. The main coordinator is a Public-Private Partnership called Amsterdam Partners (see table 1). The importance of coordination in city marketing is clear, especially when examining the everyday activities of city managers (Czarniawska, 2002). The majority of people involved in the marketing effort of Amsterdam, and all the written reports on it, attribute critical importance to the cooperation between involved parties and largely describe city marketing as a coordinating activity. City marketing, of course, is not a synonym for coordination but it does depend on integrating different policy areas and including measures to promote inter-organisational cooperation. The organisational structure the city has chosen explicitly aims at wide participation and 
extensive cooperation; in fact it is one of the strongest points of the whole marketing effort. As a next step of marketing Amsterdam, the main marketing projects were decided upon. After Amsterdam Partners was set up and the main vision was chosen, the decision was made to proceed with six main city marketing projects:

1. Cultural events.

2. The Hospitality Project.

3. New international press policy.

4. New Internet portal.

5. The 'pearl' projects.

6. A new branding campaign.

Of particular interest to this article is the branding campaign. The main idea behind the recent branding campaign was that over the past Amsterdam has had too many brand carriers, for example 'Amsterdam Has It', 'Small City, Big Business' and 'Cool City'. The new approach was based on the understanding that branding needs continuity and slogans need time to be recognised and become effective. A 'tangible' new positioning both for the city and the region was perceived as necessary, a new brand that would typify the city's benefits and values (City of Amsterdam, 2004). The new slogan for the city is 'I amsterdam' and was based on the assessment that it is clear, short and powerful. 'I amsterdam' is considered easy to remember and with great potential for people to identify with it. All the above qualities are of course subject to doubt, especially as the slogan relies so heavily on a linguistic association in a language foreign to the city's residents. The goal is for many organisations, companies and events to be able to benefit from the new brand, however not in an unrestricted manner. Brand usage is coordinated under the supervision of Amsterdam Partners.

As accepted in this article, city branding is an approach that centres on the conceptualisation of the city as a brand; and a brand is a

[...] multidimensional construct, consisting of functional, emotional, relational and strategic elements that collectively generate a unique set of associations in the public mind (Aaker, 1996, p. 68).

This construct is what should provide guidance for all marketing efforts, in order to achieve consistency in the messages sent and in such a way that the 'stories' told about the city by the brand are built in the city (Kavaratzis, 2004). There is no evidence in Amsterdam that the brand provides such guidance, a problem that arises from the inability of the slogan to convey the chosen core values of the city. As Hankinson (2004) suggests, the brand lies at the centre of marketing activities and the focus of branding activities extends 'beyond communications to include behaviour; a focus of considerable relevance to place branding' (Hankinson, 2004, p. 111). 


\subsection{Major Lessons from Amsterdam}

Several aspects of the implementation of marketing in Amsterdam are highlighted in the above. It is clear that Amsterdam has avoided two common but serious pitfalls of city marketing. First, they did not start and end all marketing efforts with an advertising campaign. Secondly, they have chosen a strategy that addresses, or intends to address, the needs not only of the tourism sector, but a wider base of economic activities and target groups. It is apparent that city marketing in Amsterdam has now reached a stage of a more refined implementation, in comparison with the past and shows signs of a demand-oriented approach, which is, of course, one of the major characteristics of marketing as a city-management philosophy. The new approach has managed to gain agreement and consensus from many parties and cooperation is carefully encouraged.

Of course in a subject as complex as city marketing and in a city as varied as Amsterdam, it would be impossible not to find negative aspects of the marketing effort. The main criticisms revolve around three major points. First, the selection of sixteen dimensions thought to represent the city and their translation first into six priority dimensions, then to three core values and, finally, to one slogan is unclear and demands a more thorough examination. Secondly, the selection of target groups is rather vague and might lead to difficulties of refining and targeting messages. Thirdly, the role assigned to city branding is not exploiting its full potential, but it is used solely as a promotional tool. A significant advantage in marketing Amsterdam is that there is a wide consensus and support on the strategy and the organisation. There is also a wide agreement that city marketing and branding are long-term activities, which need time to establish routes within the city and then be able to communicate to the outside world.

\section{THE CASE OF BUDAPEST}

Since 1989 and the symbolic fall of the Berlin Wall, the capital of Hungary, as many other cities in East-Central Europe, has found itself in an unparalleled process of transition, although this transition has been relatively smoother than in most neighbouring countries (Tosics, 2005a). City marketing was certainly not a feature of the centrally planned administration system. In recent years, however, Budapest is discovering the opportunities that city marketing can offer and there is a growing awareness of its potential particularly to support tourism in the city. Tourism in Budapest has been under competitive pressure from several cities in the wider region, like Vienna, Warsaw and Prague. This pressure has motivated the city to re-examine its competitive advantages and to redefine its tourism development strategies. The growing awareness and, to an extent, use of marketing (or at least promotion) in Budapest is a result of this 
intensified competition and the challenges it creates for the city. The marketing effort has two separate but connected goals: the first is to promote Budapest as an urban-tourism destination and attract visitors from the recently opened markets of the West based on certain attributes of the city; the second is to reestablish the city's former status as a major cultural centre in the region, through several cultural festivals and events.

\subsection{Major Issues in Marketing Budapest}

There are strong indications of the uneven and fragmented character of marketing in Budapest. Apart from the tourism sector, where certain structures are quite clear, the attempt to identify the main organisations that play an active role in marketing the city and the ones with coordinating responsibilities is not straightforward. The lack of a coordinating body is coupled by the difficulties in achieving extended structural cooperation and together they constitute the major clash between the theoretical suggestions on the importance of coordination and wide cooperation (Kavaratzis, 2004) and the practice in Budapest.

What is evidently missing from Budapest is a collective appreciation of marketing, a more general and open discussion on its usefulness and on best methods for implementation. The idea that city marketing can be useful is clearly starting to spread in the city but its implementation is unclear. This is demonstrated, for instance, in the Budapest Development Plan (Municipality of Budapest, 2003), which highlights the importance of using urban/city marketing to create an efficient economic structure in the city and to promote the city as a cultural 'melting pot' but does not specify any concrete action to attain those ends. In the tourism sector, marketing is better understood and its use is quite extensive, something that might, hopefully, lead to conceptual discussions about the future of the city and practical measures taken for a better appreciation of other goals and target markets that marketing can serve. Concerning city branding, things are even more uncertain and the city seems to be limiting its usefulness again to the tourism sector. City officials are very hesitant about encapsulating all the offerings of Budapest in one brand, which is mostly understood as the slogan - tagline under the city's name. Budapest, like large cities generally, is thought to be too complex and diverse to restrict its representation to one or two aspects. A very recent development in Budapest is the creation of a working group on city branding (for the time being it actually involves a small office with very limited human and financial resources), which has produced its first result: a new logo and slogan 'The City of Senses'. Although the logo has just been introduced and any appreciation of its effectiveness is premature, it is certainly a hopeful sign that a city branding effort has started and it is possible that this effort might lead to a better, more refined and comprehensive strategy. 


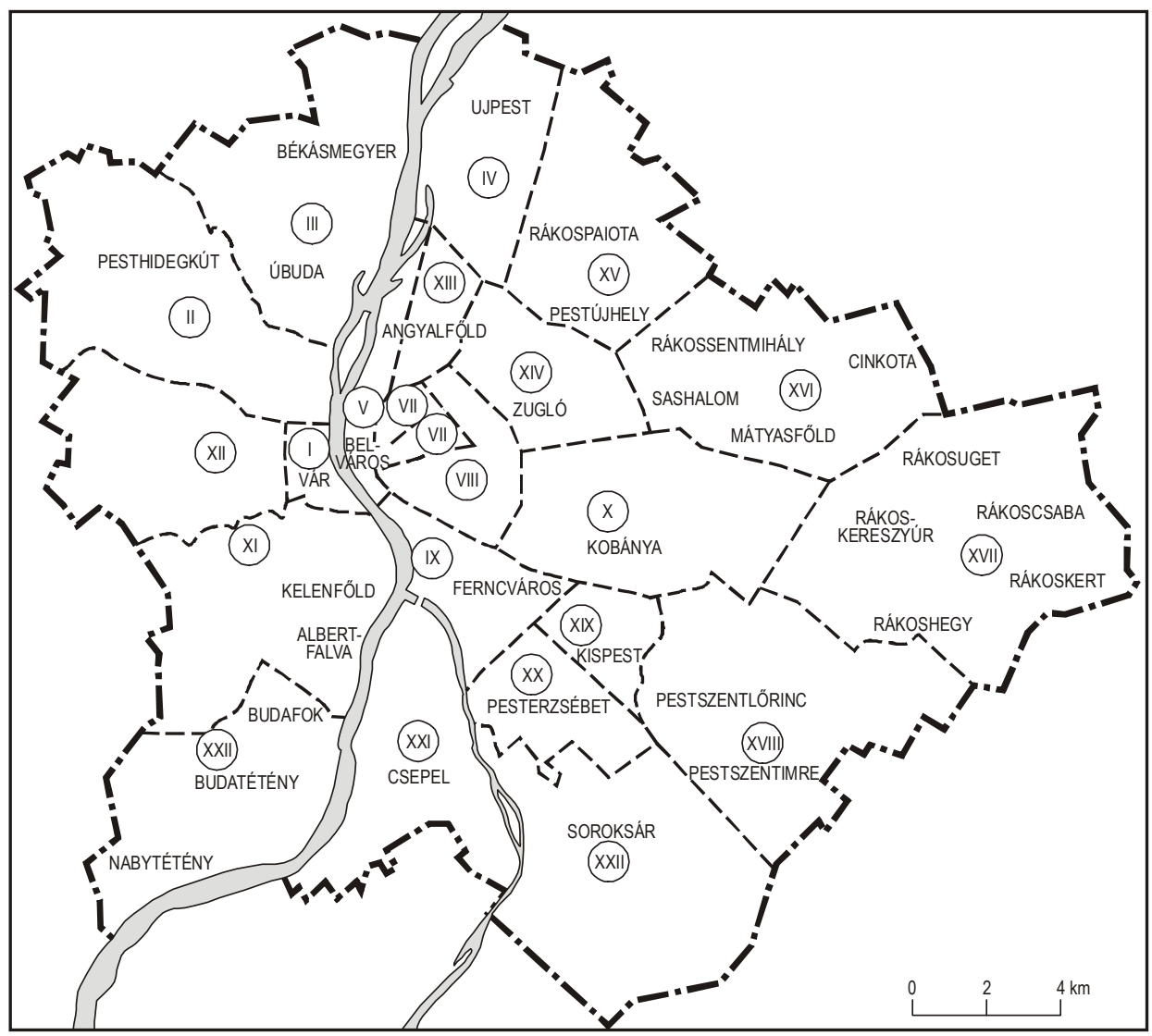

Fig. 2. The districts of Budapest

A major obstacle to any coherent city marketing effort is the administrative structure of the city. The city is divided into 23 districts, each with their own mayors and councils and there is a central municipality, which lies in the same hierarchical level as the districts (figure 2). Tosics (2005b, p. 59) accurately describes the situation as

[...] an 'equal power' two tier system, in which both levels, the upper (municipal) level and the lower (district) level are strong and can block each other.

This structure makes decision-making difficult and project implementation tricky, not least because of political tactics. As Szirmai and Barath (2005, p. 436) describe,

[...] a difficult problem was created by the rigid implementation of the principle 'strong districts weak capital'. According to the current Act on the capital, the municipality of Budapest is a federative body that is to serve the 23 districts standing on equal footing with them. The resulting 
fragmentation is chiefly responsible for the failure to work out a unified concept of urban development and the lack of clearly identified development priorities.

As far as city marketing is concerned, this situation creates significant problems and coupled with the lack of cooperation initiatives, hinders marketing implementation. As highlighted in city marketing theory (e.g. Ashworth and Voogd, 1990; Berg and Braun, 1999) and proven by city marketing practice, there is a vital need for wide agreement on general strategies, clear allocation of roles and for coordination of activities.

Appreciation of the power of marketing to promote tourism development is relatively strong as is the understanding that marketing is wider than only promotional measures. However, perhaps because of the lack of sufficient funds or because of the perceived difficulty of translating the advantages of the city into a marketable offer, the implementation is largely limited to promotional measures, with a few exceptions that confirm the rule. There is a widespread agreement within the city that, based on the city's attributes, Budapest deserves a better image in foreign countries. Those attributes however have not been translated into competitive advantages.

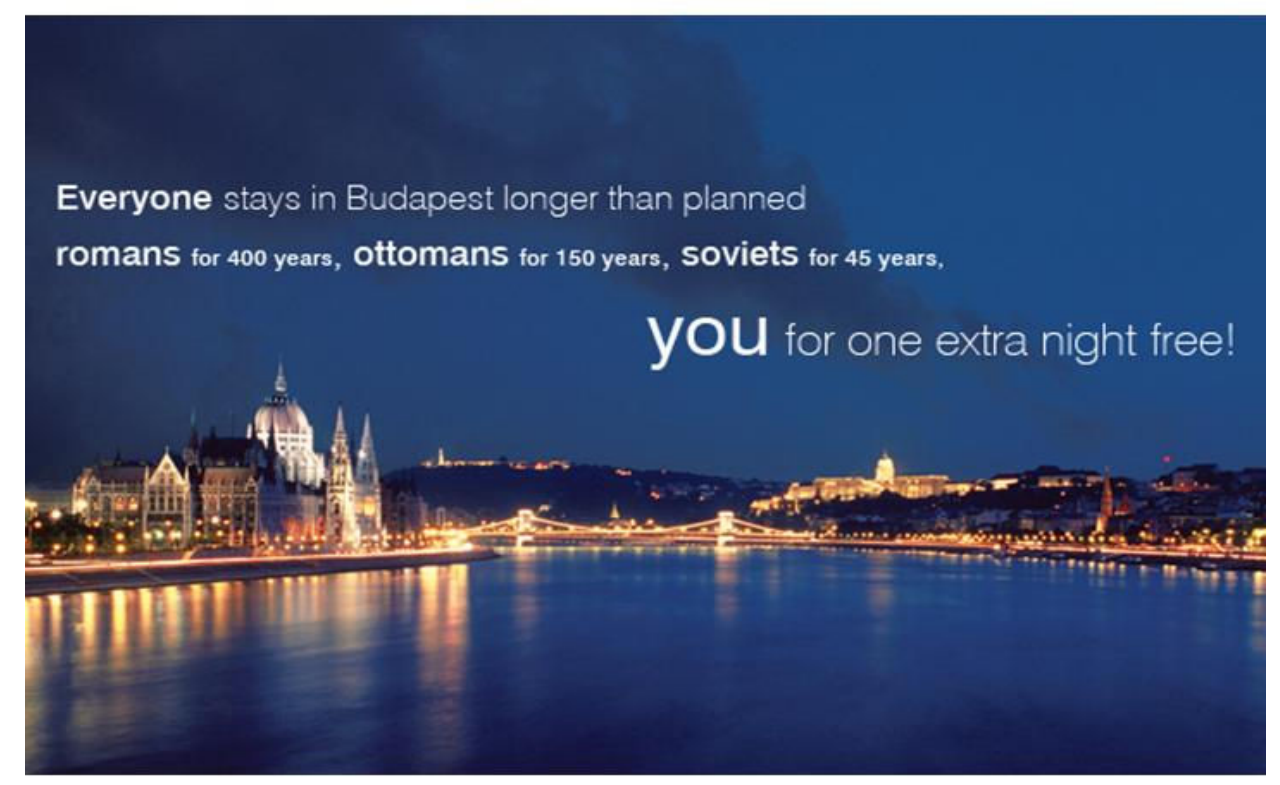

Fig. 3. Promotional poster of the winter invasion

There are two organisations that have the responsibility to manage and promote tourism growth in Budapest. First, the Budapest Tourism Office that belongs to the central municipality and is in essence a promotional agency and, 
second, the Regional Marketing Directorate of Budapest and Surroundings, which is part of the National Tourism Board and has similar goals but its funding comes from the state and its tasks cover a wider area around the city. The two organisations co-exist and cooperate in seemingly rather good terms, especially on advertising campaigns. However, current cooperation is rather informal and heavily dependent on the personal relations of the heads of the organisations, making it vulnerable to political fluctuations and possible replacement of the specific people. This can be easily attributed to the general style of operations in Hungary, which relies to a great extent on personal connections and friendly relationships; more so than most Western European countries. However, an effective cooperation would need to be more structural, involving many more organisations and stakeholders and it should not be limited to practical matters, as the case seems to be in Budapest.

Two initiatives are worth mentioning here. The first is the 'Budapest Winter Invasion' initiative, which was a joint project by the National Tourism Board, the Budapest Tourism Office, the Budapest Airport, the Hungarian Airliner Malev and approximately 60 hotels of the city. It offered visitors one extra night for free in Budapest if they booked three nights in one of the participating hotels in a certain period, aiming to spread the tourist season outside the peak period of the summer. The offer was communicated by a clever slogan (figure 3) and a special website that focused on entertainment possibilities and cultural activities in the city during the winter. The initiative has been successful and it has been repeated; a success demonstrating that the cooperation of relevant actors is necessary and can cater for greater effectiveness. The second initiative that is an interesting example of inter-city cooperation is the network 'Seven Stars of Central Europe'. This is a joint initiative of seven cities in Central Europe: Berlin, Dresden, Prague, Budapest, Vienna, Salzburg and Munich. Its goal is to promote the seven cities together in the market of the USA, taking advantage of possible synergies. It centres around a website (www. sevenstarseurope.com) with information about the cities, assistance on how to get there, links to individual websites and suggestions for sightseeing tours, events to follow and general 'things to do' in the seven cities. What is especially interesting is that in this initiative Budapest cooperates with two cities that are considered its major direct competitors: Vienna and Prague (Puczko et al., 2007). As Tosics (2005a, p. 277) though discusses,

[...] already many overseas visitors come for combined visits to Prague, Vienna and Budapest [...] in this sense these cities should cooperate to increase the joint capacities of their infrastructure instead of direct rivalry.

The Seven Stars of Central Europe, although for now only a promotional activity, is certainly a step towards that direction. 
Within the wider effort of marketing Budapest a separate focus can be identified, namely marketing Budapest as a cultural centre of East-Central European level. To a significant extent, this trend is also focusing on attracting foreign visitors and establishing Budapest as a destination for cultural tourism. Its core, however, is creating a favourable image of the city as a cultural centre both internationally but also domestically, clearly indicating an orientation towards national and local audiences. Perhaps this effort stems from a recent stagnation of tourism development in the city and the identification of the need to produce and provide new forms of values offered. It has been argued that a new attitude should be adopted that accommodates the increased importance of culture in the spatial, economic and social development of Budapest (Keresztely, 2005). Although not always consciously, marketing has been used in a wider manner to achieve this goal as, in contrast to the vague goal of generally attracting tourists, it provides a better focus and a clearer picture of what the city wants to achieve and how to achieve it. This effort concentrates on staging several cultural festivals and events in the city, demonstrating the very common view within city marketing application that events are powerful vehicles for city promotion as they generate attention to the city as a place where culture is active and attractive (Kolb, 2006). The question that remains to be answered, however, is: are all festivals appropriate and the ones organised in Budapest enough? A wide understanding of cultural events to include all leisure offerings (like that demonstrated in Budapest) might be useful for the effort of the city to attract higher numbers of visitors; however, close attention must be paid to the type and nature of these events. A certain character must be exposed by the city and not all events are vehicles to that end. The newly built national theatre and the neighbouring Palace of Arts are both evidence of Budapest's efforts to become a cultural centre and important assets that can support this effort.

\subsection{Major Lessons from Budapest}

A comparison of theoretical suggestions on city marketing and city branding and the efforts in Budapest lead to the identification of certain needs for the city's marketing to become more comprehensive and effective. First, there is a need to follow the marketing process and not undertake sporadic and only promotional activities; secondly, a stronger and wider cooperation in decisions and actions taken is a vital need; thirdly the determination of clearly defined target groups is necessary. Could the solution to the apparent problem of fragmentation lie in forming a coordinating body following the examples of other European cities such as Amsterdam Partners (see above)? Would such an organisation be viable and effective in Budapest considering the differences in public administration traditions and mentalities? 
Another clearly detected need is the expansion of marketing to other fields than tourism, because city marketing is capable of addressing wider goals and audiences (e.g. Kavaratzis, 2004). There is a need for a deeper understanding of the concept of city marketing. The usefulness of city marketing, even in the clearly more developed tourism sector, is limited to the anticipated success of the advertising campaigns launched and the numerical results of a few other promotional activities undertaken. It is the conceptualisation of city marketing that needs to be widened in order to achieve within city authorities and stakeholders a status that will allow a broader exploration of potential benefits. City marketing is not implemented as a process in Budapest but in a fragmented manner. This might be a result of the lack of knowledge and specialised people as recognised earlier in this chapter or a matter of limited resources. It can also be attributed to the general confusion of marketing with promotion, so frequently explained and clarified in the literature but still so frequently observed in practice. The efforts described above have produced positive results for Budapest and have managed to maintain the international appeal created by the 'freshness' of Budapest to the markets of the Western World. Since the regime change and in the 1990s Budapest was an exotic place disengaging itself from its socialist past (Keresztely, 2005). Recently, however, exoticism alone no longer works and

[...] the appeal of this somewhat exotic city has been fading to a growing extent, which raises the issue of the sustainability of its international appeal (Keresztely, 2005, p. 454).

Also Puczko et al. (2007, p. 1) note that 'this unique selling point has begun to wane as first-time curiosity visitor numbers are decreasing'. What happens when this 'freshness' runs out? It is then that a comprehensive and proactive marketing strategy will be most useful and when branding might prove to be crucial as creating an effective brand might work as a stabilising factor for this kind of fluctuations of conditions.

Another prevailing issue and constant charge against the application of city marketing all over the world (e.g. Griffiths, 1998) is the participation of local residents in any marketing organisation and their opportunities to influence the directions of their own city's development. It is interesting to mention at this point the movement 'I love Budapest' (www.szeretembudapestet.hu), which is a civic movement that strives to make the voice of residents heard in the city's decision making. The movement has been growing both in membership and in influence and has managed to develop a forum for discussion on the general development of the city and specific projects or sites. It played a pivotal role in the formulation of the bid for the European City of Culture and is a hopeful sign of a more active participation of the residents. 
The case of Budapest demonstrates the difficulties of transferring theoretical suggestions, especially on selecting feasible and clear goals, the importance of cooperation between actors and coordination of activities into city marketing practice; difficulties that are not only evident in Budapest but in most cities. As Tosics (2005a) concludes,

[...] the future of Budapest depends very much on the capability of the municipality to establish [a] new type of public leadership (regulating, initiating and in some regards controlling market processes) in order to support economic growth, help the fulfilment of the sustainability criteria of urban development and ensure the maximum level of solidarity (handling the problem of growing disparities between the districts, between the richer and the poorer sides of the Danube etc.).

\section{CONCLUSIONS}

Table 2 attempts a summary and parallel presentation of the main findings in the two cities referred to in this article. The table also incorporates the cities' evaluation in fundamental theoretical suggestions on city marketing as well as the elements of the theoretical framework of city branding developed by Kavaratzis (2004). Based on the findings presented in table 2, this section identifies and outlines several issues regarding city marketing and city branding that need to be better addressed in order to proceed to an improved implementation of city marketing that would increase its contribution to local economic, cultural and social development. The issues included in this section are the result of the attempt to generalise the findings of the case studies into the broader theory of city marketing. Broadly, the issues deal with two types of problems. On the one hand they concern specific difficulties facing city marketing implementation caused by political or administrative reality in the cities; on the other hand they deal with certain gaps between the theory of city marketing and the way in which it is understood and practiced in the cities.

Table 2. Main findings of the case studies

\begin{tabular}{|l|l|l|}
\hline \multicolumn{1}{|c|}{ Element } & \multicolumn{1}{|c|}{ Amsterdam } & \multicolumn{1}{c|}{ Budapest } \\
\hline 1 & \multicolumn{1}{|c|}{2} & \multicolumn{1}{c|}{3} \\
\hline Interest in marketing & High & Growing \\
\hline $\begin{array}{l}\text { Understanding of } \\
\text { marketing and the } \\
\text { marketing process }\end{array}$ & $\begin{array}{l}\text { Common/collective understanding } \\
\text { of marketing } \\
\text { Good attempt at following process } \\
\text { Strong market research }\end{array}$ & $\begin{array}{l}\text { Dependent on individuals (not } \\
\text { common) } \\
\text { Fragmented activities } \\
\text { Limited to promotion }\end{array}$ \\
\hline $\begin{array}{l}\text { Role of marketing in } \\
\text { development and goals } \\
\text { set }\end{array}$ & $\begin{array}{l}\text { Large role of marketing } \\
\text { Wide goals covering a range of } \\
\text { fields }\end{array}$ & $\begin{array}{l}\text { Limited to tourism development } \\
\text { Sensible goals for the cultural } \\
\text { centre strategy }\end{array}$ \\
\hline
\end{tabular}


Table 2 (cont.)

\begin{tabular}{|c|c|c|}
\hline 1 & 2 & 3 \\
\hline $\begin{array}{l}\text { Understanding/imple- } \\
\text { mentation of branding }\end{array}$ & $\begin{array}{l}\text { Mostly limited to promotional } \\
\text { power of branding } \\
\text { Dynamic campaign }\end{array}$ & $\begin{array}{l}\text { Limited to visual elements } \\
\text { Insufficient branding strategy }\end{array}$ \\
\hline $\begin{array}{l}\text { Development of long- } \\
\text { term vision }\end{array}$ & $\begin{array}{l}\text { Vision development debatable } \\
\text { Long-term character evident }\end{array}$ & No long-term vision and planning \\
\hline $\begin{array}{l}\text { Organisational structure/ } \\
\text { Cooperation }\end{array}$ & $\begin{array}{l}\text { Satisfactory organisational structure } \\
\text { Attempt at broad cooperation } \\
\text { Broad support for strategy }\end{array}$ & $\begin{array}{l}\text { Fragmented organisational } \\
\text { structure } \\
\text { Cooperation mostly informal }\end{array}$ \\
\hline $\begin{array}{l}\text { Involvement of local } \\
\text { communities }\end{array}$ & Not clear in vision development & Not evident \\
\hline Infrastructure & $\begin{array}{l}\text { Adequate prior state } \\
\text { Limited integration in marketing } \\
\text { strategy }\end{array}$ & $\begin{array}{l}\text { Steady improvement } \\
\text { Not integrated in marketing } \\
\text { strategy }\end{array}$ \\
\hline Landscape strategies & $\begin{array}{l}\text { Limited integration in marketing } \\
\text { strategy } \\
\text { Canals heavily used in promotion }\end{array}$ & $\begin{array}{l}\text { Not integrated in marketing } \\
\text { strategy } \\
\text { Heritage and natural landscape } \\
\text { used heavily in promotion }\end{array}$ \\
\hline $\begin{array}{l}\text { Behaviour and } \\
\text { Opportunities }\end{array}$ & $\begin{array}{l}\text { Limited efforts } \\
\text { Attempt at targeting creative } \\
\text { individuals }\end{array}$ & $\begin{array}{l}\text { Limited efforts } \\
\text { Financial incentives for specific } \\
\text { sectors (through national } \\
\text { agencies) } \\
\text { Emphasis on festivals }\end{array}$ \\
\hline Communications & $\begin{array}{l}\text { Adequate } \\
\text { Focus on people }\end{array}$ & $\begin{array}{l}\text { Adequate } \\
\text { Focus on cultural events and } \\
\text { socialist past }\end{array}$ \\
\hline
\end{tabular}

The issues raised here are the following:

1. The need for a collective understanding and appreciation of city marketing before the marketing effort starts. This common understanding contributes two benefits. First, it generates more support in favour of city marketing, precisely because of this collective appreciation of how it can support the development of the city. Secondly, it generates a common perception and a common language of communication, avoiding individual interpretations of certain issues that demand collective action.

2. The significance of a wide cooperation and clear role allocation as well as effective coordination of marketing activities. The establishment of a body that will have the task to gather together all stakeholders and coordinate actions is obviously a necessity for any marketing effort and a very basic step of city marketing implementation. It is, sometimes, enough on its own to generate 
certain dynamics that might afterwards lead to better implementation and initiatives.

3. The importance of implementing marketing as a process and not undertaking sporadic or fragmented activities. This understanding is crucial in order to prevent the commonly noticed phenomenon of only developing promotional campaigns and implementing sporadic actions with vague goals. Only then can the necessary consistency and continuity of marketing efforts be achieved and only then can the full potential of city marketing be reached.

4. The expansion of marketing understanding to fields other than tourism development. Cities are not only tourism destinations and focusing the marketing effort on attracting visitors is dangerously limiting the effectiveness of marketing but also the city's character itself. By focusing exclusively on marketing the city for tourism, the city's form and, more importantly, its spirit acquire a meaning not necessarily according to the aspirations of city residents.

5. The better comprehension of monitoring and evaluating marketing activities as to their results. Cities commonly rely on various city rankings (see above) but the methodology followed and the implicit goals of the organisations undertaking these rankings are doubtful. On the other hand, perhaps all cities can do is monitor their image and its changes, which might be enough. For instance the thorough following of the marketing campaign of the region of Groningen in the Netherlands (see Pellenbarg and Meester, 2005) has been valuable for the region's authorities and has provided information on the changes of its image and perceptions by the Dutch that have led to refinements of the campaign.

This article raises the above points in an attempt to contribute towards a process of re-examination and refinement of the concept of city marketing that might inform its future application.

\section{REFERENCES}

AAKER, D. A. (1996), Building Strong Brands, New York: Free Press.

ASHWORTH, G. J. and VOOGD, H. (1990), Selling the City: Marketing Approaches in Public Sector Urban Planning, London: Belhaven Press.

BERG, L. van den and BRAUN, E. (1999), 'Urban Competitiveness, Marketing and the Need for Organising Capacity', Urban Studies, 36 (5-6), pp. 987-999.

CITY OF AMSTERDAM (2003), Choosing Amsterdam: Brand, Concept and Organisation of the City Marketing, Amsterdam.

CITY OF AMSTERDAM (2004), The Making of... the City Marketing of Amsterdam, Amsterdam.

CZARNIAWSKA, B. (2002), A Tale of Three Cities or the Glocalization of City Management, Oxford: Oxford University Press.

European Cities Monitor (2005, 2006), available at http://www.cushmanwakefield.com 
GEMEENTE AMSTERDAM (2003), City Marketing Quick Scan, Economische Zaken en Concerncommunicatie, Amsterdam.

GOLD, J. R. and WARD, S. V. (eds), (1994), Place Promotion: The Use of Publicity and Marketing to Sell Towns and Regions, Chichester: Wiley.

GRIFFITHS, R. (1998), 'Making Sameness: Place Marketing and the New Urban Entrepreneurialism', [in:] OATLEY, N. (ed.), Cities Economic Competition and Urban Policy, London: Chapman, pp. 41-57.

HANKINSON, G. (2004), 'Relational Network Brands: Towards a Conceptual Model of Place Brands', Journal of Vacation Marketing, 10 (2), pp. 109-121.

KAVARATZIS, M. (2004), 'From City Marketing to City Branding: Towards a Theoretical Framework for Developing City Brands', Place Branding, 1 (1), pp. 58-73.

KAVARATZIS, M. and ASHWORTH, G. J. (2005), 'City Branding: An Effective Assertion of Identity or a Transitory Marketing Trick?', Tijdschrift Voor Economische en Sociale Geografie, 96 (5), pp. 506-514.

KAVARATZIS, M. and ASHWORTH, G. J. (2007), 'Partners in Coffeeshops, Canals and Commerce: Marketing the City of Amsterdam', Cities, 24 (1), pp. 16-25.

KERESZTELY, K. (2005), 'Cultural Investments in a City in Transition: The Budapest Case', [in:] BARTA, G., FEKETE, E., KUKORELLI SZORENYINE, I. and TIMAR, J. (eds), Hungarian Spaces and Places: Patterns of Transition, Pecs: Centre for Regional Studies, pp. 449-465.

KOLB, B. (2006), Tourism Marketing for Cities and Towns: Using Branding and Events to Attract Tourists, Amsterdam: Elsevier.

KOTLER, P., ASPLUND, C., REIN, I. and HEIDER, D. (1999), Marketing Places Europe: Attracting Investments, Industries, Residents and Visitors to European Cities, Communities, Regions and Nations, London: Pearson Education.

MUNICIPALITY OF BUDAPEST (2003), Urban Development Concept - Summary, Budapest: Mayor's Office, Bureau of the Chief Architect.

PELLENBARG, P. H. and MEESTER, W. J. (2005), 'Regional Marketing to Change Regional Images: The Example of the Groningen Province Campaign', Paper presented at the Academy of Marketing Annual Conference, 5th-7th July, Dublin.

PUCZKO, L., RATZ, T. and SMITH, M. (2007), 'Old City New Image: Perception, Positioning and Promotion of Budapest', Journal of Travel and Tourism Marketing, 22 (3-4), pp. 21-34.

SZIRMAI, V. and BARATH, G. (2005), 'Global Urban Development in Budapest and the Role of Architecture, [in:] BARTA, G., FEKETE, E., KUKORELLI SZORENYINE, I. and TIMAR, J. (eds), Hungarian Spaces and Places: Patterns of Transition, Pecs: Centre for Regional Studies, pp. 434-448.

TOSICS, I. (2005a), 'Post-socialist Budapest: The Invasion of Market Forces and the Response of Public Leadership, [in:] HAMILTON, I., DIMITROWSKA-ANDREWS, K. and PICHLERMILANOVIC, N. (eds), Transformation of Cities in Central and Eastern Europe: Towards Globalisation, Tokyo: United Nations University Press, pp. 248-280.

TOSICS, I. (2005b), 'City Development in Central and Eastern Europe since 1990', [in:] HAMILTON, I., DIMITROWSKA-ANDREWS, K. and PICHLER-MILANOVIC, N. (eds), Transformation of Cities in Central and Eastern Europe: Towards Globalisation, Tokyo: United Nations University Press, p. 44-78. 